\title{
Severe postoperative gastric outlet obstruction without nutritional deficiency
}

\author{
Thabet Al-Ghazal, ${ }^{1}$ Ali Ahmed Al-Zahir,' ${ }^{1}$ Sami A Al-Momen, ${ }^{2}$ \\ Abdul-Wahed Nasir Meshikhes ${ }^{\circledR 1,3}$
}

${ }^{1}$ Department of Surgery, King Fahad Specialist Hospital, Dammam, Saudi Arabia ${ }^{2}$ Department of Gastroenterology, King Fahad Specialist Hospital, Dammam, Saudi Arabia

${ }^{3}$ Department of Surgery, Al Zahra General Hospital, Qatif, Saudi Arabia

\section{Correspondence to} Dr Abdul-Wahed

Nasir Meshikhes,

meshikhes@doctor.com

Accepted 19 July 2019
D Check for updates

(c) BMJ Publishing Group Limited 2019. No commercial re-use. See rights and permissions. Published by BMJ.

\footnotetext{
To cite: Al-Ghazal T, Al-Zahir AA, Al-Momen SA, et al. BMJ Case Rep 2019;12:e231734 doi:10.1136/bcr-2019231734
}

\section{DESCRIPTION}

A 60-year-old woman presented somewhere else with haematemesis due to a bleeding duodenal ulcer. After failure of endoscopic therapy to control the bleeding, she underwent emergency laparotomy with under-running of the bleeding ulcer. She presented 6 weeks later with non-bilious vomiting of partially digested food. Gastroscopy revealed stricture in the pyloric area (figure 1A and B). Endoscopic biopsy confirmed the benign nature of the stricture. She was referred to our endoscopic service for endoscopic dilatation (figure 1C and D). After failure of three endoscopic dilatations over 6-month period, she was referred for surgery. Clinically, she looked well with no pallor or jaundice, and her nutritional status was good. The abdomen was distended but without tenderness or succussion splash. Preoperative CT scan revealed a grossly dilated stomach full of food particles with completely obstructed first part of duodenum (figure 2). Her routine bloods including albumen were within normal range. At laparotomy, the stomach was full of food debris and phytobezoars which were extracted via gastrostomy and Roux-en-Y gastro-jejunostomy was fashioned. Her postoperative recovery was uneventful and was discharged home 5 days later. She remained well and totally asymptomatic at 6-month follow-up.

Gastric outlet obstruction mechanically impedes the normal gastric emptying. It occurs in up to $2 \%$ of patients with chronic duodenal ulcer and more

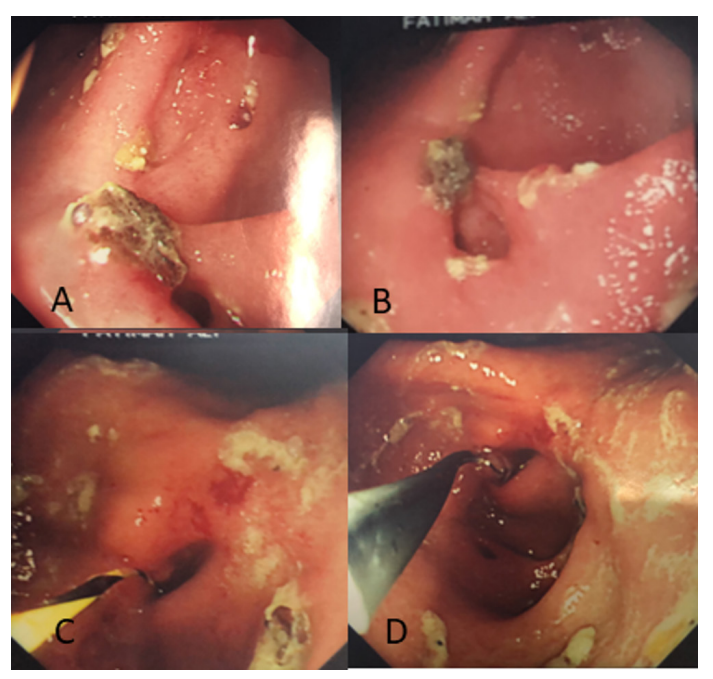

Figure 1 Endoscopic views showing the pyloric narrowing prior to second session of endoscopic dilatation (panels $A$ and $B$ ), and the second session of balloon dilatation during the ( $C$ and $D)$.

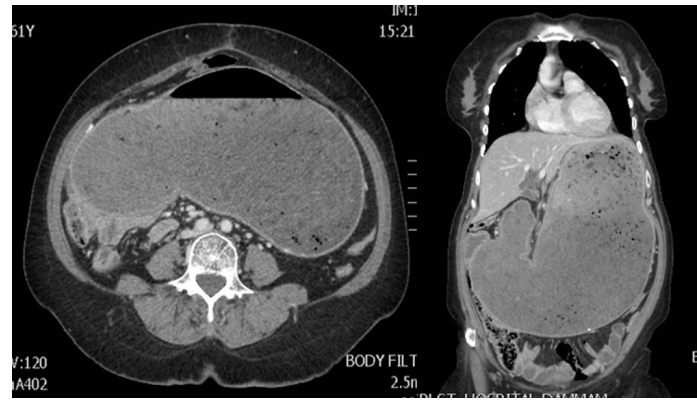

Figure 2 Axial (left) and coronal (right) CT scan cut sections showing gross dilation of the stomach; full of food debris due to severe gastric outlet obstruction.

frequently in older age groups. ${ }^{1}$ Several factors play a role in the development of benign gastric outlet obstruction including Helicobacter pylori infection, cigarette smoking and previous gastric surgery for gastro-duodenal ulcer. ${ }^{2}$ In the present case, there was neither evidence of $\mathrm{H}$. pylori infection nor history of smoking. Complaint of gastric outlet obstruction is characterised commonly by non-bilious painless vomiting, abdominal pain, loss of appetite, constipation and weight loss. ${ }^{2}$ Endoscopic balloon dilation is safe and can be used initially to dilate the obstruction but its failure necessitates a surgical bypass. Response to endoscopic dilatation may be seen after one to three sessions. ${ }^{3}$ There is little data addressing the success of endoscopic dilation for gastric outlet obstruction after surgery for complicated duodenal ulcer.

Usually, in emergency surgery for bleeding duodenal ulcer, the pylorus and part of the first part of the duodenum are opened transversely to allow bleeding control by under-running of the ulcer. ${ }^{1}$ This is closed vertically (pyloroplasty) to

\section{Learning points}

Severe benign gastric outlet obstruction can present with minimal symptoms and no nutritional deficiencies.

- Causes of postoperative gastric outlet obstruction include technical failure and poor compliance to proton pump inhibitors if no ulcer-curing surgical procedure is performed.

- The success of endoscopic balloon dilation in the treatment of postoperative gastric outlet obstruction is limited and may not obviate the need for surgery. 
avoid narrowing. Another possible reason for this narrowing is the scarring of the healing ulcer. This patient had no ulcercuring procedure in the form of truncal vagotomy at the same time, but was given a proton pump inhibitor (medical vagotomy) but the patient's compliance could not be guaranteed. We like to highlight in this case the fact that despite the gastric outlet obstruction and the massive gastric dilatation, the patient exhibited minimal symptoms and maintained good nutritional status.

Contributors TAG and AAA-Z wrote the initial draft and searched the literature. SAA-M managed the patient endoscopically and participated in writing the final draft. A-WNM was the primary physician and wrote the final draft.
Funding The authors have not declared a specific grant for this research from any funding agency in the public, commercial or not-for-profit sectors.

Competing interests None declared.

Patient consent for publication Obtained.

Provenance and peer review Not commissioned; externally peer reviewed.

\section{REFERENCES}

1 Broderick JT, Mathews JB. Ulcer complications: Zinner MJ, Ashley SW. Maingot's Abdominal Operations. $11^{\text {th }}$ Ed. New York: McGraw Hill, 2007:365.

2 Tejas AP, Jade R, Srinivas S. Gastric outlet obstruction: clinical presentations and its surgical management. Int Surg J 2018:5:622-5.

3 Kochhar R, Sethy PK, Nagi B, et al. Endoscopic balloon dilatation of benign gastric outlet obstruction. J Gastroenterol Hepatol 2004:19:418-22.

Copyright 2019 BMJ Publishing Group. All rights reserved. For permission to reuse any of this content visit

https://www.bmj.com/company/products-services/rights-and-licensing/permissions/

BMJ Case Report Fellows may re-use this article for personal use and teaching without any further permission.

Become a Fellow of BMJ Case Reports today and you can:

- Submit as many cases as you like

Enjoy fast sympathetic peer review and rapid publication of accepted articles

Access all the published articles

Re-use any of the published material for personal use and teaching without further permission

\section{Customer Service}

If you have any further queries about your subscription, please contact our customer services team on +44 (0) 2071111105 or via email at support@bmj.com.

Visit casereports.bmj.com for more articles like this and to become a Fellow 